search Organisation. It consists of an Executive of five members and of the officers comprising the staff. The Executive is the governing body. Its members will be appointed by the Governor-General, and at least three of them are to possess scientific qualifications. The chairman and two others will devote the whole of their time to the duties of office. Whereas the former Council carried sole responsibility for the scientific programme placed before the Government, provision is now made for political initiation of work, it being the duty of the Organisation to exercise its powers and functions in relation to any matter referred to it by its minister. In the important matter of staff, while the Executive may appoint such officers and employ such temporary or casual employees as it thinks necessary for the purposes of the Act, it is in each case subject to the specific direction that "the selection of persons... shall be made in accordance with such requirements as the Public Service Board determines". So, too, terms and conditions are in all cases "subject to the approval of the Public Service Board". Also, the maximum number of officers and employees whose duties are primarily of an administrative or clerical nature is similarly subject to the Board's approval. Under the earlier Act, the Council and minister settled these matters, independently of the Public Service Board. A somewhat cryptic clause towards the end of the Act runs: "A member of the Executive, a member of the Advisory Council, a member of a State Committee, an officer or an employee shall not, except in the course of his duty as such a member, officer or employee or with the approval of the Executive, disclose any information concerning the work of the Organisation or the contents of any document in the possession of the Organisation. Penalty : Imprisonment for two years." The opportunity has been taken also to effect certain minor changes which experience has shown to be desirable; but it is difficult at this stage to predict just how the new legislation as a whole will aftect established scientific activities. The sequel need not be unsatisfactory; but it is known that in some quarters the position $f$ is regarded with a measure of anxiety.

\section{Progress in Educaition}

IN his preside tial address to the National Union of Teachers at Margate on April 16, Mr. I. Gwynne Rees, of R. Talbot, outlined the extent to which the 1944 ducation Act has already been implementedX Two years ago, at a time of unprecedented diffculties, school life for every pupil in Britain was expentled to the age of fifteen. The number of teachers in primary and secondary schools is now 10 per cent greater than before the War, while the average number of pupils per teacher in the primary and secondary schools has been reduced by about 6 per cent; in the primary school, however, the average class still remains nearly 50 per cent larger than in the secondary school. These reforms, said Mr. Rees, have been made possible by the rapid increase in the supply of well-qualified teachers, provision having already been made for the training of 66 per cent more students in the permanent colleges and 44 per cent more in the universities than before the War. The other major reform necessary for the reduction in the size of classes is, he said, the provision of sufficient classrooms. In 1948 work in progress involved an ultimate capital expenditure of $£ 23,000,000$, and in 1949 the figure would be $£ 55,000,000$. There has also been remarkable pro- gress in the facilities for higher education. The toll-gate of school fees has been removed, and State scholarships and local education authority awards for further education have doubled in number since 1939. In the earlier stages of education, particular concern is being felt for the infant and junior schools, where the handicapping of the less gifted begins through lack of suitable equipment and through classes of forty, fifty and even sixty children. This seventy. fourth Conference of the National Union of Teachers was distinguished, for the first time, by the presence of the Prime Minister. In an inspiring address, Mir. Attlee declared that the prime duty of all teachers is to train their pupils to become good citizens of a democratic society.

\section{ISI Bulletin}

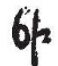

A NEW quarterly jornal, ISI Bulletin, has been issued by the Indi N Nandards Institution, $P$ Block, Raisina Road, Delhi. The price is $2 s$, and the first number ntains thirty-six pages. The Indian Standares Institution was founded in 1947, primarily as) an industrial organisation, but with Government sufport. The president is Dr. S. P. Mookerjee, Mind ter for Industry and Supply, and its director, Dr. Lal C. Verman. It has set up four executive committees for agricultural products, documentation, quality control and industrial statistics, and weights and measures, together with engineering, textile and chemical division councils, sponsoring a total of 118 committees and sub-committees. Draft standards on textile shrinkage tests and fireclay refractories have already been published. Apart from much detailed information the Bulletin contains the president's address to the general council and three very interesting general articles. The first of these, on the "Standard Atmosphere for Testing", compares average atmospheric conditions in India with those in other parts of the world and makes recommendations, which the Indian delegation was success. ful in getting accepted by the International Standards Organisation, for alternative 'standard atmospheres' to be adopted for use in industrial testing laboratories in tropical and temperate climates respectively. The second paper, on "Quality Control", is mainly a record of various conferences and papers relating to this subject, largely directed to its applications to the textile industry. The last paper deals with "Weights and Measures". It includes a brief summary of the past and present position in India, and puts forward a proposal for the adoption of the metric system with Indian names for the units, and a series of Indian prefixes and affixes to denote the successive powers (multiples and sub-multiples respectively) of 10. The Bulletin gives an impression of vitality which augurs well for the future success of the new organisation.

\section{Scientific Information in India}

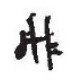

Commenting on the Royal Society's Conference on Scientific Information Services in London last year (see Nature, Angy 21, 1948, p. 279), the Journal of Scientific and Mdustrial Research (India) (Nos. 9 and $10,6 p 15,435 ; 1948$ ) emphasizes the importance fI sudh aids to research and the urgency of e volying a satisfactory system in India. It adce pts the view that the primary requirement is a cental organisation, maintaining liaison with similar organisations in other countries and directed by a man of science with width rather than depth of 
interests, who is able to perceive and satisfy the bibliographical needs of a large clientele. The needs of a really adequate information centre, for assembling scientific and technical information from India and elsewhere and for distributing such information, require consideration both from the point of view of organisation and material. The research aspect of information and intelligence work does not appear to have been recognized sufficiently in India; and the editor calls for a lead from the Indian Department of Scientific and Industrial Research towards the organisation of an efficient service on lines emphasized at the Royal Society Conference and already adopted not only by the Department of Scientific and Industrial Research in London but also in Australia, New Zealand and Canada, and by the National Researgh Council of the United States.

German Wool Industry

THE Wool Indystries-Research Association has recently prepared M.O.S. Overall Report No. 9 : The German Industry during the period 19391945" (p. P. A fondon: H.M. Stationery Office, $19481 s . \mathrm{bd})$. The report suggests that in respect of thenting, carding, spinning, weaving, dyeing, finis ling, shoddy and mungo manufacture, machinery design, operation and production there is little that the British industry can learn from its German counterpart. Much of the latter's woollen yarn industry was judged to be obsolete by American standards with, on the whole, low productivity, and, though allowance must be made for the quality of the raw material in use, the quality of work now being done was said to be poor by most of the investigators. Output was generally higher than with average Yorkshire setts ; but the standard of carding was lower. The modified Duhamel scouring process is economical in both alkali and soap, and merits careful examination. Much attention has been devoted by the Germans to by-product recovery, although there is nothing new in principle in the processes used. The exact efficiency of the German worsted industry is difficult to assess; but it would appear that while, compared with Britain, the German industry has the advantage of better build. ings, facilities and general amenities, German technicians have made no great mechanical or processing advances. Little advance in research was recorded in the war years, although some work on improving the sensitivity of wool to alkali, increasing the fastness of dyes, on moth-proofing, on low-temperature dyeing and the dyeing behaviour of the Palatine Fast dyes is noted. A bibliography of the reports and documents on which the report is based is appengled.

\section{Management Training at Staff College}

IN the paper "Tho-Staff College in Training for Management", I. N. F. Hall, principal of the Administrative s. Colff College, reviews his experimental work duf a th last two years in bringing the College ino opeption, and this paper has now been issued ify the British Institute of Management, together wit the introductory remarks of Sir Charles Renold and a report of the discussion, as the first report in the Winter Proceedings series of the Institute. Mr. Hall stresses that the task is to make a co-ordinated group out of individual specialists and to increase the capacity of those trained in administration and in different fields of technology to work together. The bulk of the work of each course is carried out by the discussion method, and this ensures that the basic principles of administration and their practical application will be examined. The study of biography has been introduced to provide opportunities for discussing the importance of personality and character in administration and to liberalize a concentrated practical course. While emphasizing the value of a well-balanced admixture of practical experience among the members of each session, Mr. Hall recog. nizes that the size of any mixed staff college must be small, both because of the importance of all members getting to know each other and because of the limits dictated by the group-discussion method used. Accordingly, great care should be exercised to avoid building up a privileged caste of those who have passed through the Staff College, from which there cannot at present be an annual output of more than about two hundred. As to the length of the course, Mr. Hall thinks it should remain at about three months or else be increased to a year; and for the present he thinks that three months represents a reasonable working compromise.

Fouad I University, Cairo: Faculty of Science

THE qual sert, 1946-47, of the faculty of science, Fored University of Cairo, gives a brief doscript of of the research activities, including par culans of papers published and some notes on researches in progress. In the Department of Pure Mathematics work is continuing on the distribution of cranial curves and on mortality tables, while in that of Applied Mathematics work is in progress on the unified field theory, the velocity potential of the fluid motion induced by the motion of a cylinder in an infinite mass of compressible fluid, and the effect of polarization on secondary scattered light. In the Department of Physics the subjects under investigation include electron polarization, viscosity of gases, electron diffraction by liquid films, the measurement of atmospheric turbulence, supersonic diffraction through slits and the viscosity of plastics. In the Department of Zoology the study of some biological and morphological aspects of lamellibranchs, the fauna of Egypt, the excretion of reptiles, and the embryology of scorpions is continuing, and a study has commenced of the anatomy, histology and physiology of the digestive system of some Egyptian Lacertilia. In the Department of Entomo. logy work continued on some of the Bombyliidæ of Egypt, and on the biology and ecology of various dung insects.

\section{The Country Journal

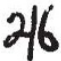

THE second number of the recently launched The Country Jour glontains a collection of articles which should gatisiy the varied tastes of those who live and w y 3 in the countryside and the unfortunate town thellers who wish to do so. There are articles for the farmer, the gardener, the botanist, the ofnithologist, the bee-keeper and the member of the women's institute; while in an admirable survey many of the recent books on natural history and rural subjects are classified for the convenience of several types of readers. In the present number of the journal two articles of absorbing interest are those by Frank Illingworth on the countryman's games and Trevor Holloway on curious country place-names. Particulars of the new journal may be obtained from the Worcester Press, Worcester. 